\title{
Völkisch versus Catholic Islamophobia in Spain: the conflict between racial and religious understandings of Muslim identity
}

\author{
Fernando BRAVO LÓPEZ \\ Universidad Autónoma de Madrid \\ fernando.bravo@uam.es
}

Recibido 3/11/2016. Revisado y aprobado para publicación 28/04/2017.

\begin{abstract}
Para citar este artículo: Fernando Bravo López (2017), "Völkisch versus Catholic Islamophobia in Spain: the conflict between racial and religious understandings of Muslim identity" en Revista de estudios internacionales mediterráneos, 22, 141-164.
\end{abstract}

Para acceder a este artículo: https://doi.org/10.15366/reim2017.22.007

\begin{abstract}
This article sets out to demonstrate that considering Islamophobia as a form of racism prevents us from fully grasping the complexity of this phenomenon. The author contends that there are different types of Islamophobia and while some are racist, others are not. To argue this point, he draws on a conflict that was sparked within a Spanish extreme right party revolving around two different conceptions of the human being and society, one rooted in the völkisch tradition and the other in the Catholic tradition. By analysing the only book the leader of that party wrote, we see how these two conceptions engendered two different types of Islamophobia: one völkisch, the other Catholic. Both share the same vision of Islam as a vital "threat" to the "West", but they differ in their understanding of the foundations of the Muslim and European identities: racist versus religious perspectives.

Keywords Islamophobia, racism, Muslims, extreme right, religion

\section{Resumen}

En este artículo se trata de demostrar que considerar que la islamofobia es una forma de racismo impide comprender la complejidad del fenómeno. Se defiende que existen diferentes tipos de islamofobia y que algunos de ellos son racistas, pero que otros no lo son. Para ello, se mostrará que en el seno de un partido español de extrema derecha se produjo un conflicto entre dos concepciones diferentes del ser humano y de la sociedad, una procedente de la tradición völkisch y otra procedente de la tradición católica. Gracias al análisis del único libro que publicó el líder del partido, veremos que de esas dos concepciones se derivaban dos tipos diferentes de islamofobia: una völkisch y otra católica. Ambas compartían una misma visión del islam como una "amenaza" vital para "Occidente", pero diferían en cuanto a cómo entendían los fundamentos de la identidad musulmana y europea: una a partir de presupuestos raciales, la otra a partir de presupuestos religiosos.
\end{abstract}

Palabras clave: islamofobia; racismo; musulmanes; extrema derecha; religión. 


\section{Introduction: Islamophobia and Racism ${ }^{1}$}

Just as the number of studies devoted to analysing Islamophobia has increased in recent years, so too the notion of Islamophobia as a form of racism has been gaining weight in academia. Indeed, this "seems to be the dominant interpretation at present" (Bagguley, 2013). The definition of this phenomenon in a wellknown international report on Islamophobia provides us with a typical example: "When talking about Islamophobia, we mean anti-Muslim racism" (Bayrakli \& Hafez, 2016: 7, 2017: 8).

This definition categorically identifies Islamophobia with racism, yet it does not explain why. It merely notes that this phenomenon does not necessarily spring from criticism of Muslims or of Islam, but is linked with power relations: how one group dominates another, in this case Muslims, turning them into scapegoats and excluding them from the "resources/rights/definition of a constructed 'we'". According to this definition, Islamophobia operates "by constructing a static 'Muslim' identity, which is attributed in negative terms and generalised for all Muslims". Finally, the report states that Islamophobia can vary in different contexts, although it does not specify what these variations consist of (Bayrakli \& Hafez, 2016: 7, 2017: 8).

Although the report's definition of racism is somewhat vague, the idea that Muslims are excluded through the construction of a "static 'Muslim' identity" appears to refer to definitions of racism akin to those proposed by authors such as Fredrickson (2002: 170): "we might say that racism exists when one ethnic group or historical collectivity dominates, excludes, or seeks to eliminate another on the basis of differences that it believes are hereditary and unalterable"; or Wieviorka (2009: 13): "racism consists of characterizing a human grouping using natural attributes that are also associated with intellectual and moral features that can be applied to each individual related to that grouping and, on that basis, adopt certain practices of inferiorization and exclusion." As in the aforementioned report, both definitions emphasize two key aspects of racism: the construction of a difference based on forming a vision of the Other's identity as natural, unalterable and hereditary, and using this difference to legitimize forms of dominance, exclusion, discrimination, persecution, etc. In step with Balibar's suggestions (1991), the line between biological racism and cultural racism becomes more blurred as differentiation between the two becomes, if anything, rhetorical, insofar as all forms of racism naturalize cultural differences. Thus, the notion of "race" is replaced with the notion of "culture" in the public discourse, but the cultural characteristics of a human group are considered as stemming from a shared origin, thus making them innate and unchangeable (Fredrickson, 2002: 7-8, 145, 169-170; Wieviorka, 2009: 42-50; see also Miles \& Brown, 2003: 103-104).

The other authors who consider that Islamophobia is a form of racism draw on different notions of "racism". Some draw on definitions such as the preceding ones (Galonnier, 2015; Garner y Selod, 2015); others approach it from the prism of "cultural racism" (Alietti \& Padovan, 2013; Modood, 1997; Dunn, Klocker y Salabay, 2007; Kumar, 2012: 3; Kundnani, 2014: chapter 2); others combine both perspectives (Grosfoguel, 2012; Grosfoguel \& Mielants, 2006); others do not specify what they understand by racism or do so rather vaguely (Selod y Embrick, 2013; Selod, 2015); and others (Meer \& Modood, 2009, 2010, 2012; Müller-Uri \& Opratko, 2016; Rana, 2007; Tyrer, 2013: 33-36) still avail themselves of a definition so broad as to result in the "conceptual inflation" decried by authors like Rattansi (2007: 8), or Miles \& Brown (2003: 57-72).

But irrespective of how they conceptualize racism, most authors invoke the notion of "racialization" to explain how a religious community -Muslims- can be the object of racism (Alietti \& Padovan, 2013; Dunn, Klocker \& Salabay, 2007; Galonnier, 2015; Garner \& Selod, 2015; Grosfoguel, 2012; Grosfoguel \& Mielants,

\footnotetext{
${ }^{1}$ This article is a reworking of pages 319-334 of my book En casa ajena: bases intelectuales del antisemitismo y la islamofobia (Bravo López, 2012). I would like to thank the reviewers of this paper and Puerto García Ortiz for their valuable comments, and Caroline Haslett for her translation. This work forms part of the project "Islamofobia: continuidad y cambio en la tradición antimusulmana: el caso de España [Islamophobia: continuity and change in the anti-Muslim tradition: the case of Spain]" (HAR2015-73869-JIN).
} 
2006; Meer, 2013; Meer \& Modood, 2009, 2010, 2012; Moosavi, 2014; Selod, 2015; Selod \& Embrick, 2013; Rana, 2007; Tyrer, 2013). Although different perspectives have been adopted (see Miles \& Brown, 2003: 99-103), "racialization" is generally taken to mean the process of ascribing natural, unchangeable and hereditary characteristics to a human group that was not previously considered as a community in these terms. As Robert Miles puts it, racialization is "a process of delineation of group boundaries and of allocation of persons within those boundaries by primary reference to (supposedly) inherent and/or biological (usually phenotypical) characteristics" (cit. in Miles \& Brown, 2003: 100). What we are dealing with, then, is a process whereby a voluntary religious identity has been transformed into an involuntary "racial" identity (Meer, 2008).

A number of factors account for this. Firstly, the increasingly numerous Muslim presence in the "West" and the ever-increasing visibility of Islam in these societies (Allievi, 2006, 2012). Secondly, the growing need to identify the "Islamic threat" apace with growing fear of Islam in these so-called "Western" societies, particularly since $9 / 11$. Hence the need to identify the "danger" and find answers to the questions "who are Muslims?" and "where are they?" - especially for the security services (Cesari, 2010; Fekete, 2009: 43-73; Hussain \& Bagguley, 2012; Rana, 2007).

But since a person's faith is invisible, other non-religious criteria have gradually taken precedence when identifying Muslims. Invariably ethno-cultural, these criteria encompass somatic features, national origin, names and surnames, ways of dressing and certain visible cultural habits. In practice, then, Muslims are not being identified on the basis of their faith but rather their supposed ethno-cultural origins, ultimately being distinguished by descent. An identity that was therefore initially determined on the basis of beliefs has become naturalized and ultimately determined on the basis of biological origin, descent. The implications are clear: the religious identity can be cast aside insofar as people can stop believing in what they believe; descent, on the other hand, is hereditary, perennial and cannot therefore be changed.

In this sense, then, determinism is a key factor in terms of how the Muslim identity is constructed: origin conclusively determines a person's identification with Islam, and, by extension, what that person is like and how he or she thinks and acts. How they are in terms of belief and behaviour is determined by who they are by descent, something they cannot change. If, moreover, a number of contemptible and threatening characteristics are associated with this inalterable identity for the purpose of legitimizing forms of exclusion, discrimination, persecution, etc., then we are dealing with a form of racism.

Everything would appear to indicate that this is indeed what has taken place in the so-called "Western world". Yet it is not enough to justify claims that Islamophobia is always a form of racism. Just because this kind of anti-Muslim rejection exists, it does not follow that all forms of anti-Muslim rejection fit the same mould. There is no evidence to uphold the theory that all forms of anti-Muslim rejection that can be considered Islamophobic amount to racism, not by a long chalk.

If we were to concede that Islamophobia is always a form of racism, but were to encounter other forms of anti-Muslim rejection that do not view the Muslim identity as "static" (Bayrakli \& Hafez, 2016: 7, 2017: 8), "hereditary and unalterable" (Fredrickson, 2002: 170), or based on "natural attributes" (Wieviorka, 2009: 13), linking it instead solely with individual religious beliefs and therefore as something that can be relinquished, we would have to conclude that these other forms of anti-Muslim rejection do not qualify as racism. As Fredrickson himself says (2002: 170): "If conversion or assimilation is a real possibility, we have religious or cultural intolerance but not racism". In other words, for racism to exist the potential inclusion of the Other must be denied (Wieviorka, 2009: 45). But if, as so many authors argue, Islamophobia is a form of racism and these forms of anti-Muslim rejection are not, because they accept the possibility of inclusion, we would have to conclude that they do not amount to Islamophobia, however radically anti-Muslim they are. These would be more akin to religious intolerance rather than racism in any form, and could not therefore be labelled Islamophobia. 
Indeed, some academics tend to categorically reject the notion that Islamophobia can occasionally also amount to a form of religious intolerance, to the point of arguing that "to reduce it to the banal question of religion" is a means of obviating its importance - or even its very existence - and relegating it to a simple matter of religious criticism (Tyrer, 2013: 5). Clearly, however, legitimate criticism of religion and religious intolerance are two completely different issues. It is one thing to contend that Muslims are wrong and altogether something else to contend that Muslims are a vital threat. Criticism of the Islamic religion is legitimate as long as it does not degenerate into demonization and a way of legitimizing discrimination, exclusion and even persecution of Muslims. Claims that the Islamic religion represents a vital threat to "us" and that Muslims, the incarnation of this religion, are also a threat and must therefore be subject to a series of measures viewed as "self-defence" (Fallaci, 2005b, 2005c), do not amount simply to criticism of Islam, but to the construction of an image of the enemy with the aim of legitimizing measures designed to forestall the danger it allegedly represents (see Bravo López 2011, 2016). Even if based on strictly religious and non-racial considerations, the consequences of this ideological construction are not "banal" at all. Proposing measures of "self-defence" - subjecting Muslims to special surveillance measures, excluding them from certain public spheres, forbidding them from entering the country, expulsion or worse- on the grounds that the faith they follow is considered threatening, has huge political and social ramifications, despite being underpinned by strictly religious criteria. This attitude undermines rights and freedoms that are part and parcel of democracy and human rights such as freedom of conscience, worship, association and expression. This kind of approach has even led to occasional calls for the Koran or Islam in general to be banned, pure and simple (Pipes, 2007). Racism is not the root of all evil. Other evils pose a threat to democracy and human rights. Religious intolerance is not the least of them, not by any means (Nussbaum, 2012).

This other type of anti-Muslim sentiment, which can be strictly religious and non-racist, is to be found particularly - but not exclusively - in certain Christian religious movements (Kidd, 2009a, 2009b; Robertson, 2011). Despite its radical anti-Muslim thrust, many of those who feel this way are prepared to concede that the Muslim identity depends on individual faith and is therefore something that can be relinquished. They accept conversion to Christianity as an option and as a means of eradicating the contemptible and threatening characteristics of the Muslim who becomes Christian (Goodstein, 2003; Smith, 2014). So, while Muslims who stop being Muslims are welcomed as "born again", irrespective of their "racial origin", those who remain true to their faith are perceived with the same violent animosity. This type of anti-Muslim sentiment sometimes encompasses the worst conceivable vision of Islam and Muslims in that it identifies them with absolute evil, with the Antichrist (see, for example, Back \& Back, 2007; Jones, 2010; Richardson, 2006, 2009; Smith, 2011). ${ }^{2}$

And yet, as noted earlier, the rationale of the dominant tendency in studies of Islamophobia would lead us to conclude that this form of anti-Muslim rejection does not amount to Islamophobia, because it is not strictly racist since it does not consider the Muslim identity as static, but rather as something that can be changed and relinquished.

We would venture the hypothesis that this insistence on considering Islamophobia always as a form of racism may well spring from the Anglo-Saxon preoccupation with "Race Relations", as a direct result of the central role ascribed to "race" in British anti-discrimination legislation. As is widely known, the 1965 and 1976 Race Relations Acts did not protect Muslims against discrimination, unlike Jews and Sikhs, who were considered as "ethnic" communities and therefore afforded protection. Muslims were considered as a religious community and were not protected as such, although they were as Asians, Africans, Arabs or Persians. In other words, any discrimination on religious grounds could not be legally pursued (Allen, 2010: 8-10; Fetzer \& Soper, 2004: 30-32; Modood, 2003; Vertovec, 2002; Weller, 2006). This may well explain

\footnotetext{
${ }^{2}$ There is also a secularized version of this vision which postulates that the only remedy to the evils of Islam is for Muslims to stop being Muslims, or to "reform" by adopting republican or liberal values (see Bravo López, 2012: 247266).
} 
why concerned activists and academics tried to right the balance by arguing that Muslims were being racialized: that while not a race - none of these "races" is really a race - they were being treated as such, and should therefore receive the same legal treatment as Jews, Sikhs, etc. (see, for example, Modood, 2003; Meer 2008; Meer \& Modood, 2009, 2010, 2012). So, rather than seeking to make discrimination on

religious grounds also pursuable by law - because it infringes on freedom of conscience - attempts were being made to integrate Muslims qua Muslims in the Race Relations system by confounding the concepts of Islamophobia and racism.

At the heart of some of these approaches, there appears to be an underlying fear that the law cannot appropriately pursue manifestations of open hostility towards Islam and Muslims because these are not being recognized as forms of racism (see, for example, Tyrer, 2013: 24-26, 31). If so, it is understandable that some activists and academics, in a bid to seek legal protection for Muslims against discrimination, opted for this action strategy of labelling Islamophobia as a form of racism. On balance, though, their strategy has contributed more to obscuring rather than shedding light not only on the phenomenon of Islamophobia, but racism too.

Although the Racial and Religious Hatred Bill of 2005 began to change the way the law protected Muslims against discrimination in the United Kingdom, by then the tendency to consider Islamophobia as racism appeared too well entrenched to resist change. Thereafter the hegemony of Anglo-Saxon academia worldwide led to a globalization of this perspective. Which brings us to where we are today, with the notion of Islamophobia as a form of racism being the mainstream tendency.

But this does not mean to say it is the only tendency, or, of course, that this is the most accurate approach. There have always been authors who have defended different views, views that tend to differentiate between Islamophobia and racism. Without denying that racist Islamophobia exists, they believe that other types of Islamophobia can also exist. Miles \& Brown (2003: 164) stated that "Islamophobia is not to be regarded as an instance of racism", while at the same time conceding that "it does interact with racism". Even Tariq Modood, who has gone out of his way to achieve recognition of Islamophobia as a form of racism or cultural racism, conceded - at least until 2005- that there was a difference between "religious Islamophobia" - an attitude he identified with the U.S. Christian right - and "anti-Muslim racism" (Modood, 2005: 122). Ali Rattansi (2007: 111) too has argued that "'Islamophobia' or any other kind of hostility to Islam and Muslims is not necessarily racist, but in many contexts can take a relatively 'strong' or 'hard' racist form". Along the same lines, Sindre Bangstad (2015) stated that "It should be clear that not all forms of Islamophobia qualify as racist", although it is true that there are "racist hard forms" this phenomenon (Bangstad, 2016).

Sure enough, there is a clear difference between the affirmations of Spanish columnist José García Dominguez (2005) - "Ten percent of all those born each year in EU territory will be slaves of Islam for the rest of their lives" - and those of Robert Spencer and Daniel Ali (2003) - "Does it really matter whether or not they [i.e. the Muslims] are introduced to Christianity? Yes, it most emphatically does"-. Indeed, this difference is one that any definition of Islamophobia should seriously consider. The first statement embodies a clearly racist conception of the Islamic identity, suffused with biological determinism; the second, a religious conception where determinism is absent. Both are hostile towards Islam and Muslims, but they conceive of the Muslim identity differently: for García Dominguez, it depends on birth and cannot be abandoned; for Spencer and Ali, it depends on beliefs and can be abandoned. Confounding these two different forms of Islamophobia as forms of racism, as if they were the same, is to distort the phenomenon.

Identifying Islamophobia with racism precludes an understanding of the complexity of this phenomenon in all its magnitude. More specifically, however, it also precludes any proper understanding of the conflicting opinions that characterize these different forms of anti-Muslim rejection, even within European 
Islamophobic movements, owing to the internal differences that exist between the different ways of understanding what forms the basis of the Muslim and European identities.

To illustrate the limitations of interpreting Islamophobia as racism and to illustrate this last point, this study analyses one of these conflicts, highlighting the differences that have existed in the bosom of a certain Spanish extreme right Islamophobic movement, between those with visions closer to the Catholic tradition and those who identified more with the neo-pagan stand of völkisch nationalism. ${ }^{3}$ This conflict did not only arise among people with different Islamophobic perceptions, but, surprisingly, is manifest in the main work published by the leader of this movement.

We can surmise that the book in question was assembled by people with these very same differences of opinion, with the resulting contradictions that appear throughout. Although the same image of Islam and Muslims as a vital threat to Europe is conveyed throughout the book, there is a basic clash of ideas concerning the foundations - ethnic or religious - of the Muslim and European identities.

This paper defends the premise that if these two different perceptions shared a same image of Islam and Muslims, then both should be construed as Islamophobia. But, since they differed in their understanding of the foundations of the Muslim identity - one drawing on religious and the other on "racial" criteria - the former should be construed as religious Islamophobia - in this case, Catholic - and the latter as racist or völkisch Islamophobia.

This paper will go on to present the case of "Plataforma per Cataluña" (PxC), one of the Spanish extreme right political parties that reaped the biggest local election victories in 2011, before its internal crisis took root. We will examine how the aforementioned clash between Catholic and völkisch perceptions materialized in stark relief within PxC, ultimately sparking an internal breakdown. This will be followed by an in-depth analysis of the aforementioned book, with the aim of showing what its blueprint for society consisted of, the image of Islam and Muslims it transmitted, and, finally, how it juggled with two contradictory visions of European and Muslim identities. We will therefore see that a same vision of Islam, mixed with two different forms of understanding the Muslim identity engendered two different and contradictory forms of Islamophobia, one Catholic and one völkisch.

This work will therefore serve to show that a more open conception of Islamophobia -as a hostile attitude towards Islam and Muslims, based on the belief that Islam is a threat to "our" wellbeing, and even "our" very survival, an attitude that can therefore manage different conceptions of the Muslim identity (Bravo López, 2011, 2016) - will enhance our understanding of this phenomenon and its social and political consequences, its different manifestations, and the contradictions and conflicts between them.

\section{The Valkyries versus the Virgin of Montserrat}

Despite his Francoist past as a former member of Fuerza Nueva, Josep Anglada (Vic, Catalonia, 1959), managed over a period of several years to carve out an important niche for himself in Catalan politics. For a while, he even managed to transform his party, Plataforma per Cataluña (PxC) into the extreme right party with the broadest institutional presence in Spain (Casals, 2009; Hernández-Carr, 2011; Guedioura, 2012). In the 2010 Catalan parliamentary elections, PxC reaped 75,000 votes even though it did not obtain a seat in parliament. In the local elections a year later, the party increased its presence in Catalonia's institutions, obtaining a total of 67 councillors. In the Vic municipality, it became the second largest political force with five town councillors. Councillors were also elected in areas such as El Vendrell (5), Santa Coloma de Gramenet (3), Salt (3) and Manlleu (3). ${ }^{4}$ After this major success, a serious internal crisis took root in PxC,

\footnotetext{
${ }^{3}$ I use the expression "völkisch nationalism" rather than other expressions such as "national-populism" or "ethnic nationalism" to highlight its identification with the tradition of ethnic German nationalism.

${ }^{4}$ Source: Ministry of nterior: http://elecciones.mir.es/resultados2011/ [accessed 10 April 2017].
} 
leading to Anglada being sacked as leader and expelled from the party, which finally took a severe thrashing in the polls in 2015 (Roger, 2015). Despite this, Anglada still represents a particularly interesting case in terms of examining how Spain's extreme right has used Islamophobia as a vehicle for its political normalization and as a tool for engendering broader social support.

It was in the context of the electoral success of PxC in 2010 that its leader decided to publish the book Sin mordaza y sin velos (No gag and no veils), supposedly written by Anglada himself, as an attempt to establish his party beyond the confines of Catalonia. The PxC leader cashed in on the presentation of his

book in Madrid in October 2010 to say that he intended to expel the Muslims from Spain - "It's going to be up to us brave souls to expel the Muslims from our country" - and to express his conviction that a Muslim could never be Spanish or Catalan: "a Moor can become a Catalan just because he can speak our language... I'll have none of that. Once a Muslim always a Muslim!" (Hidalgo, 2010). ${ }^{5}$

It is strange that Anglada expressed himself so clearly in public, speaking to the media, considering that these ideas are not enunciated half as forcefully in the book he supposedly wrote. The language and manner contained in the book differ greatly from the language and manners he tended to use in his public appearances. Whereas Anglada was given to speaking with the aim of working his audience up, his writing was more explicitly designed to convince his readers, which is why his ideas are expressed with a greater degree of sophistication than he would employ during his public addresses. This is one of the reasons why the authorship of the book was called into question from the outset. Spanish extreme right expert Xavier Casals (2010), for example, contends that the book displays "a certain patchwork or collage of elements", which would appear to indicate the work of several hands.

The book is interspersed with at least two different lines of thought, which is perhaps what paved the way for the breakup of PxC at the end of 2010. At the heart of the rupture were Enrique de Diego - who had moved closer to Anglada over the years - and Enrique Ravello, then the party's secretary for international relations ${ }^{6}$. De Diego is a journalist and regular guest on various ultra-conservative television channels, and also the founder of the Rambla publishing house that published Anglada's book as well as several books by de Diego himself devoted to warning the public about the "Islamic threat" (Diego, 2010a, 2010b). It is possible that de Diego was behind several sections of Anglada's book, especially the last one devoted to Islam and heavily influenced by the Catholic anti-Islamic tradition. Ravello, on the other hand, leans towards the premises of the neopagan völkisch nationalism of publications such as Tierra y Pueblo [Soil and People] and Europae, where he was chief editor. Ravello may well have penned the parts of the book devoted to "identity populism". Inevitably, however, there was a conflict between these two positions, one that smacks of the conflict that drove a rift in the anti-Semite movements at the end of the nineteenth century, pitting defenders of racist nationalism against those who remained loyal to the Christian tradition (see Tal, 2004: 171-190; Zimmermann, 1986: esp. 82-83, 91-92).

Indeed, this conflict still exists within Europe's extreme right, as evidenced by de Diego's distancing from PxC. De Diego himself said that his split from the party was due to the neopagan ideas spouted by Ravello, who "entertains outlandish and hallucinatory ideas about a pagan and Naziphile identity of Valkyries, nibelungs, Celtic crosses and forest gnomes, which have nothing to do with the Catalan narrative, with

\footnotetext{
${ }^{5}$ He would express similar opinions in an interview: "Un moro nunca será español" [A Moor can never be Spanish], El Mundo, 26 May 2011, see http://medios.mugak.eu/noticias/noticia/283029 [accessed 10 April 2017].

${ }^{6}$ In 2014 the party took disciplinary action against Enrique Ravello as a result of his clearly favourable stand towards Catalan independence. Eventually he resigned. See "PxC abre un expediente a Enrique Ravello... y el secretario internacional deja el partido", Mediterráneo Digital, 3 February 2014, http://www.mediterraneodigital.com/identitarios/seccion-identitarios/identitarios-3/pxc-abre-un-expediente-aenrique-ravello-y-el-secretario-internacional-deja-el-partido.html [accessed 24 April 2017].
} 
none of Catalonia's Christian roots, not by a long shot, and clearly hostile towards Montserrat, Ripoll and Poblet, towards Wifredo el Velloso, Ramón Berenguer and James I 'The Conqueror'" (Diego, 2010c). At the end of the day, Christianity ill accords with a system of thinking based on the notion that the only cultural products acceptable to a people are those it generates itself "spontaneously". Christianity, as a religion that was imported to Europe, was an oddity for an extreme right that is preaching a return to its "authentic" pagan origins.

In the second half of the nineteenth and early twentieth century, the racist extreme right came up against the same problem, with some of those who remained loyal to the Christian world view going out of their way to integrate Christianity as an essential element of Europeanness, Germanness and Aryanness. They even went as far as "Aryanizing" Christ (Heschel, 2008). A similar problem arose in Anglada's book, a problem that was addressed by incorporating Christianity as part of a culture generated spontaneously, with no external influences, by the peoples of Europe. But this obviously clashes with Christian tradition, and creates a contradiction that permeates the whole book, and that is manifested also, and specially, in the way it conceives the Islamic identity, as we will go on to see.

\section{Völkisch nationalism against "Islamization"}

All the elements of the Islamophobic discourse are present in Sin mordaza y sin velos, coupled with the key elements of the extreme right's discourse. The book's message is almost the same as the message conveyed by authors such as Fallaci, Spencer and Fjordman: Europe is decadent. Stripped of values, without hope, unaware of its identity and culture, besieged by foreign influences and by hordes of immigrants, it runs the risk of disappearing altogether. Particularly when the enemy confronting it, the enemy threatening it and invading it, is Islam, quintessentially the antithesis of Europe, its most absolute negation. Viewed from this perspective, Islam is the eternal enemy of a Europe that has built itself historically on the basis of its ongoing fight against Islam. Europe's struggle against Islam is therefore what has made it what it is. This is what defines it. If Europe were to lose its anti-Islamic character, it would no longer be Europe; it would succumb to the onslaught of Islam, which is increasingly violent. Immigration, then, is merely another weapon in the war Islam is waging on Europe, a form of invasion that will eventually take control of the continent and Islamize it. Progressive Islamization is, in fact, already a reality. It is therefore time for action; we must defend ourselves and avoid the ominous fate looming over us: Islamization. The time has come for Europe to rouse itself from its lethargy after being numbed by a culture of deceit and "political correctness", by the lies spouted by a trendy lefty political, intellectual and media elite that is essentially anti-Western, anti-European and anti-Christian to the core. It is this very same elite that is responsible for the state of decadence enveloping Europe, an elite that hates everything that Europe stands for, an elite that wants to destroy its roots, its identity and is willing to use Islam to achieve this, to the extent of establishing a real alliance with this absolute enemy. Islam and the left are involved in a huge conspiracy to do away with Europe and the West. The tyranny of the "politically correct" language, what can and cannot be said in public, so successfully imposed by the trendy lefty elite, has given wings to this conspiracy. As a result, people do not know what is going on and they are afraid to say what they think. But a group of leaders has emerged from among the people, working for and on its behalf. They are not afraid and they have decided to raise their voices and to fight Islamization. They are the leaders of the "identity-populist" movement, Anglada among them. These are the leaders who have decided to rouse the country from its sleep, to make the people realize that the "putrid caste of politicians" (Anglada, 2010: 39-62), of intellectuals and media are misleading them, manipulating them at will to fuel their own obscure interests, and they are encouraging Islamization. This, then, is Anglada's mission: to rally the people to join the fight against Islamization. 
Broadly speaking, this is the message conveyed in Sin mordaza y sin velos. But beyond this apocalyptic description of present-day Europe as a victim of growing Islamization, Anglada -or whoever wrote the book- also offers a political project revolving around society, a "solution" to the problems and dangers identified in the book: "identity populism".

"Identity populism" is merely a euphemism employed repeatedly throughout the book to refer to völkisch nationalism and this alone (on the ideology of völkisch nationalism see Mosse, 1961, 1998; Puschner, 2002; Stern, 1974). It is odd that a work so committed to "exposing" the lies of "political correctness" has to disguise its discourse in a sea of euphemisms. But the explanation for this is simple, notably the situation in which the extreme right found itself after World War II, when it was obliged to modify its discourse to make it more socially acceptable, particularly when seeking to become integrated in mainstream politics and participate in elections. Scratching the surface, however, the key ideas of the classical extreme right reappear in Anglada's text, rooted in the völkisch tradition: the concept of a community based on blood and soil -Blut und Boden-, the need for living space or the now notorious Lebensraum, anti-Marxism, a backlash against the Enlightenment, a rejection of universalism, a rejection of the party system, populism, the defence of the community's cultural homogeneity, defence of tradition, defence of the traditional family against the "excesses" of feminism, etc.

One of the key aspects of this tendency to mask the extreme right's traditional discourse is the use of the "new racism" or "cultural racism" discourse, in which racial terminology has been replaced by a culturalist terminology (Balibar, 1991; Stolcke, 1995). Occasionally, however, the text cannot resist succumbing to the strength of the tradition of the extreme right, resorting to undeniably racist expressions. Anglada, for example, criticizes the ideas propounded by the Lebanese professor Fawaz A. Gerges, accusing him of wanting to "do away with our cultural bases", "in the own interests of his race" (Anglada, 2010: 300). But this explicitly racist reference is an exception in the book. More commonplace, as noted earlier, is the culturalist discourse that avoids any reference to the idea of race. But, as was the case with "classic" racism, this discourse radically confounds cultural and biological elements: genetic makeup determines culture. And thus it is that biological concepts such as those linked with genetics are used repeatedly and ever so easily to refer to cultural issues. We therefore hear Anglada, obviously referring to Islam, contending that "'conquest' as the true manifestation of the faith is a wrought-iron element of the DNA of this religion", asserting further on that "Muslims are basically warriors and conquerors", something that "is genetically entrenched in the very origins of their ideological religion" (Anglada, 2010: 272 and 278).

There can be no doubt that origin is the determining factor of Anglada's völkisch nationalism; for this reason, any cultural aspect that can be identified with a people or nation can be considered a product of its genetic inheritance. A community, says Anglada, -once again confounding biological and cultural elements - is "a river of blood", clarifying that he means it "in a cultural or anthropological rather than racial sense" (Anglada, 2010: 88). How can a community based on blood and descent be understood in a cultural sense unless culture itself is conceived as genetically determined? In other words, for Anglada, the community is a blood community that, for this very reason, is cultural. This culture is exclusive to this people, to this community, because it is transferred genetically rather than on the basis of exchanges with other peoples. The underlying notion is that the foundation of a community, a people, is the link between parents and children and that this link is inextricably linked to cultural production and, therefore, that the conservation of a people's culture hinges on conservation of its genetic legacy or, in other words, on what classical racism terms "its racial purity". A "racially pure" people is, therefore, the sole guarantee of a genuine "own" culture. Foreign genetic or cultural contributions represent an undesirable interference in the ordinary course of matters; they would undermine the people's biological and cultural heritage, its authenticity, its identity, and its very survival as a people. Therefore, the integration of foreigners -those that do not belong to the people by descent - is emphatically opposed: 
Since peoples have their own identity, one that is the product of a peculiar creative tradition, we reject outright the possibility of what some sociologists term "cultural integration". Nobody is entitled to impose a specific tradition that is foreign to another people, because we would be breaking a natural law (Anglada, 2010: 88).

The main task of any self-respecting people - understood as a blood community - is therefore to preserve its cultural -linked with genetic - heritage. The mixture that can be engendered by contact with other peoples should be therefore be avoided at all costs. All peoples should remain isolated from one another as much as possible, within their own territory. One people, one nation, one soil. Blood and soil. A people's destiny, defined by its blood, is inextricably linked with the destiny of its soil. All peoples are therefore entitled to their own "vital territory" (Anglada, 2010: 90), and they are obliged to defend it because on this depends the preservation of their heritage.

From this perspective, immigration upsets the ideal system of strict separation between peoples because it causes individuals of different descent and cultures to live on the same territory. Multiculturalism is a crime because it threatens the cultural identity of both the immigrant and the autochthonous individual:

Any people with its own identity naturally needs a specific territory in which to develop and perpetuate itself, which is why we also reject the notion of "multiculturalism". There is no room for contradictory identities on the same soil because in the end one will end up imposing itself on the other/s (Anglada, 2010: 88).

Multiculturalism -identified solely as a product of immigration - threatens the ideal image of homogeneity, purity and authenticity, of the people, of the community. This is because Anglada believes that a people should be culturally homogeneous, as a product of its blood link. Indeed, for Anglada, the people he claims to represent is already culturally homogeneous; this is what defines it as a people: "what gives meaning to, and explains, the existence of a people is this common background, these religious beliefs, and moral values, ethical principles, cultural traditions and customs, which have gradually taken shape as a homogeneous and coherent whole" (Anglada, 2010: 86). Accordingly, if the community shares a single moral, a single ethic, a tradition, a religion, it should share the same concept of Good and Evil, a same idea of what should or should not be done, a same spirit. This is indeed the case. ${ }^{7}$ Anglada ascribes the existence of internal political discrepancies, if any, to alien ideologies introduced in a bid to change the people, to make it something it is not. Political parties, therefore, should represent the people and not try to change it. Democracy, in this sense, should operate on the basis of values that are specific to the people and not on the basis of universal values, which do not exist because each people produces its own through "spontaneous generation". Democracy "is not an ideology", Anglada says (2010: 68), it does not champion a series of values, but is merely a system of government through which the people governs. Politicians should rule according to the dictates of the people and since the people only has one moral -one that Anglada believes emanates from natural law, "Christian humanism" and tradition (Anglada, 2010: 103) —, governing on behalf of the people means governing in accordance with the principles of this moral.

Democracy, as understood by Anglada, is a somewhat peculiar system. Here we have a form of democracy that is "spontaneously generated" by the people and which must incarnate the essence of this people, and in which only the real members of the people are entitled to participate, where ideological pluralism is seen as something evil and where individual freedom should always be placed at the service of the community, without ever transcending the limits imposed by tradition (Anglada, 2010: 122). Understood thus, it is hardly surprising that Anglada views "identity populism" as "profoundly democratic" (Anglada, 2010: 81). If the people is one and has one sole moral, the existence of political parties does not make much sense. If this intrinsic unity is ubiquitous, there should be no disagreements, no discord, and it would be natural for just one party to exist. The party that really defends the interests of the people, its traditions and identity,

\footnotetext{
${ }^{7}$ Anglada's insistence on this idea of total homogeneity is curious, to say the least, considering that his own party was internally divided and that this division eventually led to a breakup.
} 
that embodies its values and ideas, should be its only and legitimate representative. This sole party vocation is evident in PxC:

We have said that a party is an association with an end purpose. Obviously, the end purpose of some parties is ideological: they want to change or rebuild society on the basis of a roadmap drawn up by some enlightened soul who, in his infinite and prodigious wisdom, has dreamt up a perfect society that has never occurred to anybody before him. Since we believe it is only possible to design the future through the progress that tradition represents, i.e., the "spontaneous generation" made by the people overall, we are not, nor do we want to be, nor can we be, an ideological party.

Ideological parties divide a single people between those who believe and those who do not share these ideas. Our party, Plataforma, on the other hand, is transversal in the sense that we want to represent the entire people and not just part of it (Anglada, 2020: 116-117).

In other words, it is not just immigrants who are threatening the people and its unity, but also the "ideological" parties, especially left-wing ones. These want to change the people, transform it into something else, because deep down they hate it. They are anti-Spanish, anti-European and anti-Christian.

This is why they facilitate immigration, especially Muslim immigration, which is specifically anti-Spanish, anti-European and anti-Christian. They are therefore traitors who want to do away with the people; they are internal enemies and part of the problem. Their supposedly favourable stand towards Muslim immigration makes this clear:

This stupid bonhomie which consists of ushering in those who want to destroy our democracy and destroy our community is a betrayal of the nation, a betrayal of the people and an intractable paradox on the part of those who call themselves democrats and tolerant, because it is their weakness that will bring about the day when democracy and tolerance are things of the past.

How can they not realize this? Is it not enough for them to see what happened to civilisations that were so ahead of their time, such as those of Egypt or Rome?

The reason is simple. They are not satisfied with the people, they do not feel comfortable within the community. They dream and aspire to a people that is different to what we are, they are fighting for a community that is different to the one we form, you and I (Anglada, 2010: 91).

Anglada, therefore, clearly identifies an internal enemy bent on corrupting "our essence", and an external enemy "threatening us" from outside and now, thanks to the "trendy lefty betrayal", also from inside.

\section{The Islamic "threat"}

Islam, as Anglada makes clear from page one onwards, is the absolute, eternal and essential enemy. If Europe has defined itself in counterposition to anything, that anything is Islam. This much is made clear in the prologue, written by Heinz-Christian Strache, chairman of the Freedom Party of Austria (FPÖ): "our identities as nations have been forged in the struggle against Islam, acting as real barricades against the challenge of the Muslim civilization. Neither Spain nor Austria would be what they are without this common characteristic that defines us" (Anglada, 2010: 13-14).

It is in the fight against Islam that Europe, the idea of Europe and its identity, have been built. This essential feature of Europe's identity, however, has been forgotten, concealed by the tyranny of what is considered to be "politically correct". Europeans have therefore forgotten what they are, what defines them. They have stopped confronting Islam and Islam has gained the upper hand. Through immigration, Islam has 
penetrated our society, which it is gradually conquering through Islamization. Total Islamization is the future awaiting Europe if it fails to react in time. This is the scenario Anglada presents, to which end he resorts to the well-known strategy - used also by anti-Semites ${ }^{8}-$ of introducing a futurist panorama where this ominous fate is already a reality. The year is 2025; Islam practically dominates everything, a situation that has been brought about by respecting the basic rights of Muslims, by allowing them to continue being Muslims. They were allowed to open mosques; religious symbols were removed from public institutions; Muslims were allowed to continue following their customs; they were allowed to vote and so they voted for Islamist parties that want to establish sharia law (Anglada, 2010: 17-19). This is now a reality: 2025, the year of final Islamization and it is already too late to do anything about it. But today, with Islamization yet to culminate, it is possible to act, and acting means following the ideas of "identity populism", Anglada's ideas. He has the solution.

Before taking action, we must be clear that Islam is effectively an enemy. It is essential to combat the ideas established by the tyranny of "political correctness" and make the "real character" of Islam quite clear. Anglada prides himself on being "politically incorrect" and daring to say what others keep to themselves (Anglada, 2010: 27). He dares to speak the simple truth: Islam, all of it, is the enemy. There is no such thing as good Islam. The notion of a moderate Islam is simply "a gross mistake demonstrating the crass ignorance of a bunch of know-it-all intellectuals regarding Islam" (Anglada, 2010: 330). All Muslims, as people subject to Islam, are the enemy. There is no difference between them. As for those living in Spain, they are "all fundamentalists" (Anglada, 2010: 419). All Muslims believe that their religion obliges them to conquer the whole world, to Islamize it, since the "mandate of all loyal Muslims who emigrate is to Islamize the ground they tread" (Anglada, 2010: 361). Indeed, a perfectly planned strategy has existed "from the very same moment the Koran was written: the Islamization of the world, either through conversion or force" (Anglada, 2010: 395, original emphasis). As far as international relations between Islamic and non-Islamic states are concerned, this translates into an ongoing and inevitable conflict, a clash of civilizations, whose existence Anglada does not doubt for a second (Anglada, 2010: 297-300). This same "clash of civilizations" is taking place in those European countries that have allowed Muslim immigration (Anglada, 2010: 261262).

Muslim immigrants arrive in Europe and they do not change. They hold on to their beliefs, their customs and their ideas. They continue to be Muslims and therefore they are still the enemy. They will always place the sharia over and above any national laws (Anglada, 2010: 279). And since they are duty-bound to Islamize the world by virtue of the sharia, this is exactly what they are doing in Europe: trying to Islamize it. The fact is, on settling in our countries, they have not changed their way of thinking, behaving and expressing themselves. They still feel the same way and pursue the same aims as in their countries of origin, but with the aggravating factor that here they are pressured to extend their beliefs in order to "convert us", because, I repeat, Islam is basically an ideological and clearly expansionist religion (Anglada, 2010: 280).

Immigration is therefore a new form of aggression, a weapon used by Islam in its strategy of conquest, of global Islamization, a "Trojan horse" (Anglada, 2010: 277-280). Immigrants, once here, amass in certain areas with the clear aim of removing themselves from the authority of the State and replacing this with

\footnotetext{
${ }^{8}$ See, for example, the picture Louis-Sébastien Mercier (1740-1814) paints for 2440: "The Jews increased almost supernaturally, under the contempt of the nations who became so tolerant of them that they finally thought the time had come to revive the Mosaic Law and announce it to the world (...). We did not want great bloodshed and this people, for its part, were prepared to renew all the horrors that its history offers, and of which it has been the agent or the victim. You allowed this ferment which was silently penetrating all the countries of Europe to lie dormant (...). Its furore terrified us for it seemed to want no one left alive on the globe except believers attached to Mosaic law (...). Decisive action had to be taken to repress the ferocious superstition." (Mercier, 1787: vol. 3, 177-183; cit. in Poliakov, 1984: 151).
} 
sharia law, creating a State within a State (Anglada, 2010: 267-268) ${ }^{9}$. Thanks to their exponential demographic growth and the ageing of the autochthonous European population, these immigrants would soon become a majority. They are, in fact, a real demographic threat (Anglada, 2010: 283-285).

Availing themselves of the rights we have so naively granted them, they will then manage to impose themselves, take power and Islamize society. The "Islamization of the world" does not correspond to the "desire of a specific and radicalized group of Muslims, but is rather a specific and literal mandate handed to them by Allah in The Koran", and therefore incumbent on all Muslims who, "to the extent that they are believers, cannot shake off this moral obligation". Their diasporas will therefore "fight with all the means available to them to replace Christianity and the secular civic values that have shaped European Western civilization with sharia law, legitimized by the desire of the divinity" (Anglada, 2010: 414). And all of this is encouraged and facilitated by the trendy liberals, who insist on being tolerant. They know what Muslims are like and yet they continue to defend the "trendy-lefty theory of multiculturalism", calling for Muslims to be respected "in keeping with the democratic tolerance they, these Muslims themselves, lack completely and which they arrogantly view with contempt" (Anglada, 2010: 74-75).

Anglada, on the other hand, believes that intolerance should be met with intolerance, "intransigence with intransigence" in the case of "those who are endangering democracy". This means intolerance towards

Islam, but also towards other ideologies -such as Marxism- that he does not consider to be democratic either (Anglada, 2010: 76, 396) ${ }^{10}$. So while Islam is the enemy, equally dangerous are those who help it, who facilitate its growth, those whose anti-Spanish, anti-European and anti-Christian hatred makes them want to see Islam triumph. The left, in this sense, is part of the problem. In its zeal to transform society, to turn the people into something else altogether, the left is attacking Christianity and identity populism and promoting multiculturalism. Allowing different cultures to live side by side in the same territory and undermining the unitary nature of the people is the left's favourite tool for implementing its transformation strategy. This strategy will in time lead to the people's true identity becoming so blurred that nobody will be able to distinguish it, marking a decisive step towards its final transformation. Moreover, the introduction of Islam will be a fundamental weapon in this left-wing strategy to place all these religions on an equal footing and thus do away with the Christian values underpinning European society. This is a new "Molotov-Ribbentrop Pact", an alliance between the trendy left and Islam to do away with the "West" and its values (Anglada, 2010: 405-416).

\section{Fabricating the image of the enemy}

But how does Anglada go about constructing the image of the Islamic threat? He resorts to two tactics: the authority of a series of authors, and the use of the Koran as proof that the threat is real, that the very essence of this religion and its sacred text is the origin and cause of the evil Islam embodies.

As far as the first tactic is concerned, Anglada goes out of his way to cite a great many intellectual authorities to back up his statements on each page of the book, aiming to give the impression that his arguments are well founded. However, hardly any information is ever given regarding the origin of the

\footnotetext{
${ }^{9}$ Anglada does not use the expression "State within a State", given its obvious anti-Semitic roots, but rather the euphemism "subgroup within a country's legal group", but the meaning is obviously the same. The "State within a State" image was an integral part of the European anti-Semitic discourse (see Katz, 1969).

${ }^{10}$ Following this very same logic, this intolerance could be applied to Anglada himself, given his clear intransigence with any attitudes contrary to his own. Meeting "intolerance with intolerance" -a widespread slogan in the Islamophobic discourse- is, like "an eye for an eye", the quickest way to make us all blind and eliminate the practice of tolerance in general.
} 
sources cited. The aim is clearly to make it difficult to check the veracity of the quotes used, because in many cases Anglada's citations are distorted or simply false. On other occasions, he resorts to blatant plagiarism, putting someone else's words into his own mouth. More often than not, the author's determination to come across as an intellectual force to be reckoned with is pathetic, not least in the light of his academic background and political track record. Suffice to say, the book is peppered with Latin, English and even Arabic phrases.

Several examples can be cited to demonstrate this spurious use of other authors' work. When citing the words of Jordi Moreras, a lecturer at Rovira i Virgili University and an expert on Islam in Catalonia, Anglada says "the term diaspora provides a framework for analysing the processes and strategies developed by the different Muslim communities in Europe to preserve and safeguard their collective identity" (Anglada, 2010: 267). However, for obvious reasons, he avoids quoting the rest of the sentence, as follows: "and achieve their satisfactory and non-confrontational integration in European society" (Moreras, 1999: 29). Further on, apparently citing ambassador José María Ferré de la Peña word for word, Anglada contends that:

The "majority" trend in present-day Islam is "traditional and fairly intolerant; predominating among the most religious" there is another "extremist trend going as far as fanaticism", substantiated by "experts on traditional Islam, but interpreted selectively. They legitimize violence and even terrorism" (Anglada, 2010: 271, original emphasis).

The original text, in fact, differentiates between four trends within Islam: a majority trend, an extremist trend, a liberal trend and a Sufi trend. What Ferré de la Peña actually says is that this extremist trend "goes as far as fanaticism, but with very few adherents" (Ferré de la Peña, 2008), a qualifying statement Anglada prefers to omit.

This pattern is repeated with a text by Fred Halliday, altered to the extent of becoming almost unrecognizable (Anglada, 2010: 357; see Halliday, 2005: 188-189). The same holds true when Anglada cites Abul A'la Maududi (Anglada, 2010: 359; Maududi's original text in Elorza, 2002: 200), eliminating his references to the Christian theocracy and to the form the Islamic government should take. He also eliminates Maududi's ideas concerning each Muslim's right to interpret the law of God, since this contradicts what Anglada repeats ad nauseam: that the sources of the law cannot be interpreted, that there is "no room for argument and they cannot be modified or interpreted on a whim" (Anglada, 2010: 330). Anglada even goes as far as distorting a text by Daniel Pipes, not exactly a renowned Islamophile. Anglada uses this text to legitimize his idea that "Islam is incompatible with democracy", when Pipes clearly states that he does not share this idea and that "Islam, like all pre-modern religions is undemocratic in spirit. No less than the others, however, it has the potential to evolve in a democratic direction" (Pipes, 2008; Anglada, 2010: 357). Earlier, Anglada even plagiarized a text by Pipes himself, citing the words of Fouad Ajami, Olivier Roy, John Eposito and Leon Hadar taken from an article Pipes wrote, but which is not cited anywhere in the book (Pipes, 1995; Anglada, 2010: 327).

This form of using quoted sources is repeated, as expected, when the Koran is cited. As with other Islamophobic authors, everything that does not tally with the image of Islam Anglada is trying to project is eliminated from the quoted texts. Islam, evil as it is, cannot appear to be diminished. It must come across as wicked to the core, so there can be no room for nuances. When, for example, Anglada cites verses 2:190-191, where God calls on believers to fight on his behalf, he fails to include the proviso at the beginning of verse 190, "those who fight you but do not transgress. God does not like transgressors". Needless to say, he does not cite the next verse, 192, "And if these cease, then God is forgiving and merciful" (Anglada, 2010: 335; for the Spanish original version see El Corán, 2005: 31-32). When he reproduces verses 8:17-18 Anglada adds the words "the unbelievers", which are not in the original text. He also alters the text of $4: 77$, and when he cites 8:60, calling on the believers to prepare for war, Anglada fails to mention that the next verse also calls on them to accept peace: "If they incline to peace, then incline to it also!" (Anglada, 2010: 335-336; El Corán, 2005: 89-90, 178, 183). Even more manipulative is the translation of verse 9:5 which Anglada renders as "If they convert, establish prayer and give zakat, leave 
them be!", when both Julio Cortés' translation - which Anglada purports to use - and Juan Vernet's say "if they should repent" (Anglada 2010: 336; see El Corán, 2005: 188; El Corán, 2008: 156-157).

Even though Anglada claims to use Cortés' Spanish translation, he occasionally uses Vernet's instead -as is the case with verses 8:7-8-, but without clarifying this. This is because Cortés uses the words "remove the disbelievers", whereas Vernet says "exterminate the disbelievers down to the last man," which Anglada doubtless found more appropriate (Anglada, 2010: 334; see El Corán, 2005: 177; El Corán, 2008: 148).

In short, Anglada uses the Koranic text and the texts of the contemporary authors he cites as he sees fit, always with the aim of endorsing a pre-established image of Islam. If the text is in line with what he considers "true Islam", he cites it verbatim. If this is not the case, if it can be construed as contradicting the image he wishes to convey, then he has no qualms about altering the text so that it says what he wants it to say.

As with other Islamophobic authors (see Bravo López, 2012: 207-343; Peters, 2006), the Koran is allimportant in terms of serving to characterize Islam as the absolute enemy. In this case, Anglada devotes ten pages of his book to citing excerpts from the Koranic text (Anglada, 2010: 333-343). He then goes on to cite verses to support some of his arguments (Anglada: 2010: 361-362, 364, 373-376, 378). Needless to say, in doing so he is clearly out to demonstrate that everything he says about Islam is confirmed in its sacred book. The Koran provides conclusive evidence concerning any doubts that may arise regarding the true nature of Islam. If anyone doubts what Anglada has to say, if anyone does not believe that Islam is as he portrays it, all they have to do is pick up the Koran, for there they will find everything they need to know:

But there is something that nobody can deny nor hide for much longer from our people. And that is to compare all the information I have provided in this chapter with what the Koran literally says, and which I have reproduced in the next chapter. You may be surprised to discover the indisputable connection between what the Islamists actually do and what the Koran establishes in its pages as the "word directly revealed by Allah". Because if the Koran did not exist, there would doubtless be no Islamists (Anglada, 2010: 327-328, original emphasis).

The mandate of the Koran, then, is clear: "holy war against the unbeliever, only de-escalating with complete Islamization of the world" (Anglada, 2010: 347). And since the Koranic text cannot be altered and there is only one way of interpreting it - since its teachings "brook no discussion", and "they cannot be modified or interpreted on a whim" (Anglada, 2010: 330)-, there is only one Islam. There is no such thing as a moderate Islam and a radical Islam; there is just one Islam. It is for this reason, says Anglada, that "those who believe we can achieve an Islam of Europe, as something that differs from traditional original Islam, are completely missing the point" (Anglada, 2010: 288, original emphasis). Nor is there any such thing as a moderate Muslim, just a way of being Muslim, which is why being both Muslim and European is impossible, because, as made clear earlier, Muslims are the enemy of Europe and, by definition, by Koranic mandate, they want to do away with Europe, transform it into its antithesis, Islamize it.

\section{What makes a Muslim Muslim?}

Anglada is forever trying to build an essentialist image of Islam, characterized by wickedness, intransigence, intolerance, fanaticism and its hunger for conquest. Islam has been thus since the outset and has not changed throughout its history. In fact, it cannot change, it is impossible; its very essence makes it the way it is: "Can Islam evolve? Absolutely not", says Anglada (2010: 352). The Koran made it thus and forever. So Muslims are a threat mainly because they blindly follow the mandates of the Koran. If the Koran did not 
exist, there would be no Muslims either, or Islamists: "because if the Koran did not exist, there would doubtless be no Islamists" (Anglada, 2010: 328, original emphasis). It is, therefore, their religion that makes Muslims a danger. Therein lies the root of all evil. But what would happen if Muslims were to abandon Islam? Can Muslims stop being Muslims and thus stop being a danger?

Nowhere is the essential contradiction between the Catholic and völkisch visions more evident than here. Whereas Anglada's entire political project, this "identity populism", is wholly based on classic assumptions of völkisch nationalism, his entire vision of the antagonism between Europe and Islam is, for the most part, based on the Catholic anti-Islamic tradition. And both conceptions are obviously at odds regarding the nature of the Muslim identity.

When Anglada tackles the issue of the origins of Islam, he cannot avoid introducing an explicitly racist perspective, because of the völkisch influence. Like the racists of the nineteenth and the first half of the twentieth century (Kidd, 2006: 168-202), in certain passages Anglada toys with the notion that religion is a product of something pre-existent, something that shapes it: race, or what he specifically calls "the nature of the people". He contends that Islam is the product of the Arab people, of its character, its "nature". The essence of the Arab people has passed over to Islam and shaped it, making it what it is: an "ideological religion" of expansive and violent nature. The "nature of the Arab people" is nomadic and conquering, therefore "the osmosis between Arab and Muslim in this sense is indisputable. Islam, then, is Arabic culture" (Anglada, 2010: 369). The culturalist discourse commonly followed by the European extreme right does not speak of the "Arab race"; it uses instead the terms "nature" and "culture" indiscriminately, the reason being that a people's culture and its genetic legacy -its "nature" - are conceived as inseparable.

From the völkisch perspective, then, the characteristics of Islam are determined by its Arabic origin: "Islam is inseparable from the Arab culture. It is anchored in its foundations, its DNA", says Anglada somewhere else (Anglada, 2010: 288). In other words, an Arab would possess all the characteristics associated with Islam even if he were not a Muslim, even if the Koran had never been written and Islam had never existed. In this case, a Christian Arab would not really be Christian: he would behave according to his Arab nature and would therefore possess the same characteristics the nature of the Arab people conveyed to Islam. Conversely, a person of European descent who converts to Islam can never be a true Muslim because that person's origin, his blood, the blood of his people, would determine his culture, which would in turn determine his behaviour, which could never be truly Islamic. The answer to the question "Can a Muslim stop being a Muslim?" would therefore be yes, provided he or she is not of Arab origin. A Muslim of Persian, Berber or European origin, for example, could relinquish Islam and stop being a danger. An Arab Muslim, on the other hand, could never stop being a danger even if he or she were to stop being a Muslim and become a Christian.

This logical conclusion, however, which inevitably tallies with the völkisch approach, directly contradicts the argument propounded time and time again in the book, influenced by the Catholic vision, which is that Christianity and Islam are antithetical and that a Christian and a Muslim, therefore, bear absolutely no resemblance, irrespective of their ethnic origin. Consequently, a Christian, even of Arab origin, cannot share the same characteristics as a Muslim, even if the latter were of European origin. A Muslim, even if of Persian, Berber or European origin, could not free himself of the characteristics associated with Islam because these stem from the teachings of the Koran and Muhammad, and these teachings are universal because Islam "is a religion that brings together all human beings without distinction" (Anglada, 2010: 345). In other words, anyone, irrespective of his or her ethnic origin, can be trapped by these teachings. But can they abandon them and stop being Muslims, becoming and being treated instead as equals in European societies?

The conceptual chaos that this contradiction between racial and confessional perspectives engenders could not be clearer. Anglada describes Islam as an "ideological religion", a "code that is not only religious but also moral and political", one that turns Muslims into "basically warlike and conquering beings", a "genetically entrenched" condition (Anglada, 2010: 75, 278, our emphasis). Thus they end up subject to Islam, like robots blindly following Koranic teachings to the letter, which is why their personal capacity "to 
decide and discern is negligible" (Anglada, 2010: 351). Those who practice Islam cannot "by any means escape from the dictates of the sacred text of that religion" (Anglada, 2010: 332). There is no possible alternative: this is what Muslims are like. To be otherwise, they would have to stop being Muslims, something they will never do, "because distancing themselves from the verses of the Koran would be tantamount to saying they are no longer believers of Islam, which is something they will never do" (Anglada, 2010: 332). So they will continue being Muslims and will therefore continue to reject and combat democracy; they will try to subvert the system, establish Sharia law and, in short, Islamize us.

Some passages of the book are imbued with determinism, from which it follows that once a Muslim, always a Muslim. This overtly biological determinism postulates that Muslims are Muslims because of their descent, as demonstrated by the fact that the idea of the existence of a supposed Islamic demographic threat is considered (Anglada, 2010: 283-285). This idea presupposes that the Muslim identity is something acquired at birth, something that is handed down directly as a result of one's descent; in other words, religious beliefs are inherited, they are determined by blood and they cannot be relinquished.

But from the confessional perspective, a Muslim can stop being a Muslim; he can stop following the teachings of Islam. The door is left open to the possibility of change: "Those who do not practice Islam naturally cannot be qualified as Islamists". But straight away, in the same sentence, the völkisch perspective closes that door again: "although the fact of belonging to that community has shaped their way of thinking, just as Christianity shapes ours even if we are not believers, in line with the idea put forward of tradition and the spontaneous generation of progress" (Anglada, 2010: 332). Here, their "background", the "community", is no longer merely Arab, it is Muslim. The Muslim identity is thus racialized, the conclusion being that Muslims can never stop thinking like Muslims, even if they are not believers. Change is not possible.

Further on, however, change does appear to be feasible again. The books reads: "(...) for a Muslim to accept the Western political model, he would simply have to renounce his faith. And we would then no longer be

speaking of European Muslims but rather ex-Muslims in Europe" (Anglada, 2010: 353). The author goes on to cite, approvingly, a number of prominent ex-Muslims such as Ibn Warraq, Farag Foda and Nasr Hamid Abu Zayd (Anglada, 2010: 353-354). A Muslim, then, cannot change while he remains a Muslim. The Muslim will never accept democracy. This same Muslim will not even share "our" same conception of the human being: "Muslims will never accept our way of understanding the human being for the simple reason that it is not theirs, that of their tradition" (Anglada, 2010: 355). However, Muslims can apparently stop being Muslims, in which case everything changes. Those who abandon Islam have, at the very least, managed "to accept the Western political model". Or perhaps not, because they still belong to another culture through their descent, their blood... And since democracy and this very same conception of mankind, as perceived by Anglada, stems from the "spontaneous generation" of the community with which he identifies -and is exclusive to that community - then abandoning Islam would not allow Muslims to share conceptions that are not part and parcel of their "culture", of their "nature". Clearly, then, the clash between the Catholic and völkisch visions in the book is patent from start to finish.

Sometimes it looks as though an invisible hand has corrected the passages written from the Catholic perspective in an attempt to accommodate the völkisch framework, completely disregarding the contradictory and absurd nature of the end result. This core contradiction can be glimpsed throughout the book, even in the vision of the community Anglada himself identifies with. From the confessional perspective, Christianity is considered to be a determining factor in building the identity and way of thinking of European nations, but at the same time, from a völkisch perspective, it is argued that for any given people - understood as a blood community-, the only acceptable cultural manifestations are those that it "spontaneously engenders". The only way of defending both perspectives simultaneously would be 
to consider Christianity as a religion that has emerged spontaneously in Europe, although Anglada does not go that far. And so the contradiction remains intact, seemingly inadvertently.

\section{Removing a tumour}

After presenting the threat, a solution had to be proposed. In order to do so, however, the contradiction that appears throughout the book had to be resolved. If Islam is an absolute evil, if this evil is incarnate in every single Muslim, if these Muslims - as per the völkisch viewpoint - are Muslims by birth and can never stop being Muslims - even if they stop being believers - then, by allowing Muslim immigration, we would be "inoculating, in our very midst, the cancer that could destroy Western civilization" (Anglada, 2010: 272273). So if Muslims never change and cannot stop being Muslims, neither can they stop being a threat, a "cancer" for "Western civilization". If the cancer is not curable, then the cancerous tumour has to be removed.

Conversely, if -in accordance with the Catholic perspective - there was a remedy to the evil Muslims represent, if Muslims could change and stop being Muslims, then the cancer could be cured: Muslims would simply have to be made to abandon Islam. Was this the solution?

Oriana Fallaci tackled the same question in her last book, but concluded that there was no solution to the Islamic "problem" in Europe, because the only option would imply doing away with democracy (Fallaci, 2005a: 63-67). Anglada, on the other hand, appeared to suggest that if democracy is used as it should be government of the people by the people, based only on values rooted in the real and particular tradition of the people-, there could be a solution and, moreover, a "democratic" one. What the people want is what would be done. This would be democratic by definition, as is everything emanating from the people through "spontaneous generation". What is more, since PxC was the only party truly representing the people, everything it proposed would be democratic. It was the only party that was democratic and loyal to the essence of the people. But what, then, was the solution?

This is where the staunch supporters of "identity populism" would be really disappointed because there is no talk of removing the cancerous tumour, no question of expelling all Muslims, as Anglada stated in a public speech. As Enrique Ravello himself emphatically stated, "the only solution is to repatriate these hordes of immigrants" (Ravello, 2010). However, the solution proposed in the book was far from going to these extremes. According to Anglada, Islam had to be set apart from all other religions and subjected to specific measures translating into less public subsidies - at least while "discrimination against women" was not expressly abandoned-, banning the veil, obliging imams to preach in one of Spain's official languages, and monitoring activities in mosques "to ensure in situ that terrorism was not, under any circumstances, being encouraged" (Anglada, 2010: 422-423).

From the perspective of "identity populism", it could be inferred that the presence of "strange cultures" in the territory of the community with which Anglada identified undermined its cultural identity and was a crime, a threat to its survival; the more so if this presence was Islamic. So how could measures focused on controlling Islamic worship be perceived as a solution? Clearly, when the author of the book had to tackle the business of coming up with a solution, he doubtless viewed as too extreme the logical conclusions to which the völkisch perspective led, because they effectively involved eliminating the Muslim presence in Europe. All the measures proposed were explicitly linked with religion, with Islamic worship; none targeted the preservation of the ethnocultural integrity of the people with whom Anglada identified, with preventing the entry into the country of "persons alien to our culture" (Anglada, 2010: 90), or, needless to say, the expulsion of Muslims already resident in the country. Nor did they favour any special discrimination against Muslims regarding labour, housing, health, etc., beyond those measures targeting all immigrants in general, on the "Spaniards first" principle. So, concerning the treatment that should be meted out specifically to Muslims - disregarding their ethnic origin-, the book once again dismisses any racial approach, opting instead for a confessional angle, but failing to show even any special missionary concern geared to encouraging Muslims to progressively abandon their religion. Rather, the book espouses 
a model similar to the one practiced in the last decades of Franco's dictatorship for all religious minorities in Spain: a system based on strict control and surveillance of their practices, reducing them to an inferior status.

\section{Conclusion}

It is a mistake to consider that there is only one type of Islamophobia. And doubly wrong to consider that this one type is racist in nature. Different types of Islamophobia exist and they differ according to the different contexts in which they appear and the different ideologies of the Islamophobes. Left-wing Islamophobia, for example, cannot be construed on equal terms as right-wing Islamophobia. Nor can the Islamophobia professed by a Catholic be exactly the same as the Islamophobia professed by a Protestant, atheist or neo-pagan. Differences exist even within the extreme right, as this article has made clear.

Anyone with Islamophobic leanings has to reconcile his or her ideas concerning Islam with other ideas that are also important to them, ideas about God, the human being, science, the family, social, economic and political order, etc. And the type of Islamophobia that emerges will be conditioned by the nature of these ideas. All these different types of Islamophobia coincide in their view of Islam and Muslims as a vital threat to the wellbeing -indeed the very survival - of the communities with which they identify. But they differ as far as other ideas go, which is why they often differ in their conception of what constitutes the mainstay of the Muslim identity. Some consider it to be voluntary, the product of individual beliefs, something that can be learnt or relinquished; others view it as involuntary, the product of one's descent, determined by origin, something that can be neither learnt nor relinquished. Others still, perhaps the majority, see it as voluntary in theory, but involuntary in practice. Some believe that Muslims can change and become "good", others that this change is impossible; and others, again probably a majority, consider theoretically that change is possible whereas, in practice, they act as though it were impossible.

This article has shown how two types of Islamophobia, present in the same political sector, have clashed and been pitted against one another. Two different conceptions of the human being and society coexisted within the same Spanish extreme right political party, one völkisch and the other Catholic, engendering two

different types of Islamophobia. The conflict between these two conceptions finally led to a breakup within the party, but before that, it was mirrored in the only book the party leader wrote to advertise his ideas. The book attempts to reconcile the two conceptions, but fails miserably, engendering overlaps and contradictions that are patent throughout. These contradictions mainly concern the way in which the foundations of identity were understood, both the identity of the community the party aspired to represent and the Muslim identity.

Tensions and contradictions between these two conceptions loom large throughout the book. Racial and confessional conceptions of the Muslim and European identities appear side by side. In the case of the former, culture is determined by blood, by one's origin; in the case of the latter, it is determined by religious beliefs. The racial conception zeroes in on origin, which cannot be altered; the confessional conception concedes that change is possible. In consequence, the racial conception holds that Muslims can never be accepted in the community, whatever they do; but the confessional conception says the opposite is true, if Islam is abandoned. The conflict between these two irreconcilable visions of the foundations of identity ended up sparking an internal division within the party, between the partisans of the Valkyries and those of the Virgin of Montserrat, to revert to Enrique de Diego's terminology.

Despite this fundamental conflict between two different visions of identity, the vision of Islam conveyed in the book is consistent throughout. As regards the overall vision of Islam as a vital threat to the "West", the contents of the book do not differ in the slightest from the contents of other Islamophobic texts. We find 
the same description of an intrinsically violent, intolerant, destructive religion, fashioned thus from the outset by the teachings of the Koran and Muhammad. For this same reason, Islam is frozen in time, incapable of developing or transforming itself. Likewise, all Muslims are characterized as robots, as blind and irrational followers of the teachings of the Koran and Muhammad, and therefore as violent and intolerant chauvinists bent on dominating the world, subjecting it to their God, Islamizing it. Meanwhile, Europe is portrayed as decadent and decaying, as a continent subject to the tyranny of a trendy liberal corrupt elite bent on misleading the people and prepared to destroy its roots and identity, to which end it has no qualms about selling it to the Islamic enemy, which, thanks to this betrayal, is advancing, imposing itself and Islamizing the continent.

In short, what we have here is the same vision of Islam, the same vision of Muslims, but different visions of the basic elements that define the Muslim identity: one derived from the völkisch tradition, another derived from the Catholic tradition. This is what we find in Anglada's book. However, if we were to swallow the hegemonic discourse contained in studies of Islamophobia and accept that it can only ever be a form of racism, then we would only be able to consider Islamophobia as that vision of Islam and Muslims based on the völkisch conception. But not only that: we would be incapable of differentiating between one conception and another, and incapable of identifying the contradictions that arose when attempts were made to reconcile the two. We would think that the entire book only reflects one type of Islamophobia the only type that supposedly exists, the racist type-, and that it contains no contradictions as regards the conception of the Muslim - and European - identity; and finally, that the book does not point to any conflict between two different forms of Islamophobia. As a result, we would be incapable of really understanding what this book reflects. In short, the notion that Islamophobia can only ever be a form of racism prevents us from analysing the reality of this phenomenon in all its complexity.

As stated in the introduction, this is precisely why Islamophobia must be viewed as a phenomenon accommodating different sensibilities, as an attitude that is present in different ideological sectors and which can therefore take different forms, some racist and others not. On balance, and as argued by Miles \& Brown, Rattansi and Bangstad among others, Islamophobia is not a form of racism, although in certain ideological spheres and some socio-political contexts it may have a racist character.

\section{References}

ALIETTI, Alfredo \& PADOVAN, Dario (2013): "Religious racism: Islamophobia and antisemitism in Italian society", Religions, no. 4, pp. 584-602. https://dx.doi.org/10.3390/rel4040584.

ALLEN, Christopher (2010): Islamophobia, London, Ashgate.

ALLIEVI, Stefano (2006): "How the Immigrant has become Muslim. Public debates on Islam in Europe", Revue Européenne des Migrations Internationales, vol. 21, no. 2, pp. 135-163.

- (2012): "Reactive identities and Islamophobia: Muslim minorities and the challenge of religious pluralism

in Europe", Philosophy and Social Criticism, vol. 38, no. 4-5, pp. 379-387. https://doi.org/10.1177/0191453712444423.

ANGLADA, Josep (2010): Sin mordaza y sin velos, Madrid, Rambla.

BACK, Roland L. \& Back, Michael A. H. (2007): What is the Antichrist-Islam connection?, 2nd ed., s.l., Gardners Books.

BAGGULEY, Paul (2013): "Xenophobia and Islamophobia in Europe, by Raymond Taras", Ethnic and Racial $\begin{array}{llllll}\text { Studies, } & \text { vol. } & 37, & \text { no. } & \text { 8, } & \text { pp. }\end{array}$ http://dx.doi.org/10.1080/01419870.2013.851401.

BALIBAR, Étienne (1991): "Is there a 'neo-racism'?", in Balibar, Étienne \& Wallerstein, Immanuel (eds.): Race, nation, class: ambiguous identities, London, Verso, pp. 17-28.

BANGSTAD, Sindre (2015): "The racism that dares not speak its name: rethinking neo-nationalism and neoracism", Intersections, vol. 1, no. 1, pp. 49-65. http://dx.doi.org/10.17356/ieejsp.v1i1.26. 
- (2016): "Islamophobia: what's in a name? analysing the discourses of Stopp Islamiseringen av Norge (Stop The Islamisation of Norway, SIAN)", Journal of Muslims in Europe, no. 5, pp. 145-169. https://dx.doi.org/10.1163/22117954-12341324.

BAYRAKLi, Enes \& HAFEZ, Farid (eds.) (2016): European Islamophobia report 2015, Istanbul, SETA.

BAYRAKLI, Enes \& HAFEZ, Farid (eds.) (2017): European Islamophobia report 2016, Istanbul, SETA.

BRAVO LÓPEZ, Fernando (2011): "Towards a definition of Islamophobia: approximations of the early twentieth century", Ethnic and Racial Studies, vol. 34, no. 4, pp. 556-573. http://dx.doi.org/10.1080/01419870.2010.528440.

- (2012): En casa ajena: bases intelectuales del antisemitismo y la islamofobia, Barcelona, Ed. Bellaterra.

- (2016): "Islamophobia" in STONE, John, et al. (eds.): The Wiley-Blackwell encyclopedia of race, ethnicity and nationalism, Oxford, Malden MA., Chichester, Wiley-Blackwell. http://dx.doi.org/10.1002/9781118663202.wberen058

CASALS, Xavier (2009): "La Plataforma per Catalunya: la eclosión de un nacional-populismo catalán (20032009)", Working Paper, Institut de Ciències Politiques i Socials, no. 274, http://xaviercasals.files.wordpress.com/2009/11/wp2741.pdf [accessed 24 April 2017].

- (2010): "El populismo que viene (26): 'Sin mordaza y sin velos' o la reinvención de Anglada", Blog de Xavier Casals, 11 July, https://xaviercasals.wordpress.com/2010/07/11/el-populismo-que-viene-26-sinmordaza-y-sin-velos-o-la-reinvencion-de-anglada/ [accessed 28 March 2017].

CESARI, Jocelyne (2010): "Securitization of Islam in Europe", in Cesari, Jocelyne (ed.): Muslims in the West after 9/11: religion, politics and law, Abingdon \& New York, Routledge, pp. 9-27.

DIEGO, Enrique de (2010a): Chueca no está en Teherán: contra el caballo de Troya del multiculturalismo, Madrid, Rambla.

- (2010b): Islam: una visión crítica, Madrid, Rambla.

- (2010c): "Enrique de Diego confirma su ruptura con la PxC de Anglada", MediterráneoDigit@l.com, 2 December, https://webbeta.archive.org/web/20101205013650/http://www.mediterraneodigital.com:80/barcelona/enrique-dediego-confirma-su-ruptura-con-la-pxc-de-anglada.html [accessed 24 April 2017].

DUNN, Kevin M.; KLOCKER, Natascha \& SALABAY, Tanya (2007): "Contemporary racism and Islamaphobia in Australia. Racializing Religion", Ethnicities, vol. 7, no. 4, pp. 564-589. https://doi.org/10.1177/1468796807084017.

El Corán (2005), 9th ed., edition and translation by Julio Cortés, Barcelona, Herder.

- (2008), introduction, translation and notes by Juan Vernet, Barcelona, Planeta.

ELORZA, Antonio (2002): Umma: el integrismo en el Islam, Madrid, Alianza Editorial.

FALLACI, Oriana (2005a): El Apocalipsis. Oriana Fallaci se entrevista a sí misma, Madrid, La Esfera de los Libros.

- (2005b): "El inútil diálogo que el islam rechaza desde hace 1400 años", La Nación (Buenos Aires), 19 July.

- (2005c): "Italia y el arte, las próximas víctimas", La Nación (Buenos Aires), 20 July.

FEKETE, Liz (2009): A suitable enemy: racism, migration and Islamophobia in Europe, London \& New York, Pluto Press.

FERRÉ DE LA PEÑA, José M. (2008): "Islam y política en Europa y en Asia: algunas reflexiones comparativas", in FARRÉS, Oriol (ed.): Anuario Asia Pacífico 2008, Barcelona, Casa Asia, Fundación CIDOB \& Real Instituto Elcano, pp. 333-343.

FETZER, Joel S. \& SOPER, J. Christopher (2004): Muslims and the State in Britain, France, and Germany, Cambridge, Cambridge University Press.

FREDRICKSON, George M. (2002): Racism: a short history, Princeton, Princeton University Press.

GALONNIER, Juliette (2015): "The racialization of Muslims in France and the United States: some insights from white converts to Islam", Social Compass, vol. 62, no. 4, pp. 570-583. https://doi.org/10.1177/0037768615601966.

GARCÍA DOMíNGUEZ, José (2005): "Es la yihad y está aquí", Libertaddigital.es, 7 November, http://www.libertaddigital.com/opiniones/opi_desa_27989.html [accessed 4 April 2017]. 
GARNER, Steve \& SELOD, Saher (2015): "The racialization of Muslims: empirical studies of Islamophobia", Critical Sociology, vol. 41, no. 1, pp. 8-19. https://doi.org/10.1177/0896920514531606.

GOODSTEIN, Laurie (2003): "Seeing Islam as 'Evil' Faith, Evangelicals seek converts", The New York Times, 27 May.

GROSFOGUEL, Ramón (2012): "The multiple faces of Islamophobia", Islamophobia Studies Journal, vol. 1, no. 1, pp. 9-33.

GROSFOGUEL, Ramón \& MIELANTS, Eric (2006): "The long-durée entanglement between Islamophobia and Racism in the Modern/Colonial Capitalist/Patriarchal World-System", Human Architecture: Journal of the Sociology of Self-Knowledge, vol. V, no. 1, pp. 1-12.

GUEDIOURA, Hassen (2012): "La forte croissance de Plataforma per Catalunya: á l'aube d'un nouveau national-populisme en Espagne?", Hérodote, no. 114, pp. 163-181. http://dx.doi.org/10.3917/her.144.0163.

HALLIDAY, Fred (2005): El Islam y el mito del enfrentamiento, Barcelona, Bellaterra.

HERNÁNDEZ-CARR, Aitor (2011): "¿La hora del populismo? Elementos para comprender el «éxito» electoral de Plataforma per Catalunya", Revista de Estudios Políticos, no. 153, pp. 47-74.

HESCHEL, Susannah (2008): The Aryan Jesus. Christian Theologians and the Bible in Nazi Germany, Princeton, Princeton University Press.

HIDALGO, Susana (2010): "Josep Anglada presenta en Madrid su apología del racismo", Público.es, 8 October, http://www.publico.es/espana/340557/josep-anglada-presenta-en-madrid-su-apologia-delracismo [accessed 24 April 2017].

HUSSAIN, Yasmin \& BAGGULEY, Paul (2012): "Securitized citizens: Islamophobia, racism and the 7/7 London bombings", The Sociological Review, vol. 60, no. 4, pp. 715-734. http://dx.doi.org/10.1111/j.1467954X.2012.02130.X.

JONES, Terry (2010): Islam is of the Devil, Lake Mary, Flo., Creation House.

KATZ, Jacob (1969): A state within a state; the history of an anti-Semitic slogan, Jerusalem, Israel Academy of Sciences and Humanities.

KIDD, Colin (2006): The forging of races: race and scripture in the Protestant Atlantic world, 1600-2000, Cambridge \& New York, Cambridge University Press.

KIDD, Thomas S. (2009a): American Christians and Islam. Evangelical culture and Muslims from the colonial period to the age of terrorism, Princeton, Princeton University Press.

- (2009b): "Evangelicals, the End Times, and Islam", Historically Speaking, vol. 10, no. 1, pp. 16-18. https://doi.org/10.1353/hsp.0.0004.

KUMAR, Deepa (2012): Islamophobia and the politics of empire, Chicago, Haymarket Books.

KUNDNANI, Arun (2014): The Muslims are coming! Islamophobia, extremism, and the domestic War on Terror, London \& New York, Verso.

MEER, Nasar (2008): "The politics of voluntary and involuntary identities: are Muslims in Britain an ethnic, racial or religious minority?", Patterns of Prejudice, vol. 42, no. 1, pp. 61-81. http://dx.doi.org/10.1080/00313220701805901.

- (2013): "Racialization and religion: race, culture and difference in the study of antisemitism and Islamophobia", Ethnic and Racial Studies, vol. 36, no. 3, pp. 385-398. http://dx.doi.org/10.1080/01419870.2013.734392.

MEER, Nasar \& MODOOD, Tariq (2009): "Refutations of racism in the "Muslim question»", Patterns of Prejudice, vol. 43, no. 3-4, pp. 335-354. http://dx.doi.org/10.1080/00313220903109250.

- (2010): "The racialisation of Muslims", in Sayyid, Salman \& Vakil, Abdoolkarim (eds.): Thinking through Islamophobia: global perspectives, London, Hurst \& co., pp. 69-83.

- (2012): "For 'Jewish' read 'Muslim'? Islamophobia as a form of racialisation of ethno-religious groups in Britain today", Islamophobia Studies Journal, vol. 1, no. 1, pp. 34-53.

MERCIER, Louis-Sebastien (1786): L'an deux mille quatre cent quarante, rêve s'il en fut jamais, nouvelle édition, 3 vols., s.l., s.n.

MILES, Robert \& Brown, Malcolm (2003): Racism, 2nd ed., London \& New York, Routledge.

MODOOD, Tariq (1997): "Introduction: the politics of multiculturalism in the new Europe", in Modood, Tariq \& Werbner, Pnina (eds.): The politics of multiculturalism in the new Europe. Racism, identity and community, London \& New York, Zed Books, pp. 1-26. 
- (2003): "Muslims and the politics of difference", The Political Quarterly, vol. 74, no. 1, pp. 100-115. http://dx.doi.org/10.1111/j.1467-923X.2003.00584.x.

- (2005): Multicultural politics: racism, ethnicity, and Muslims in Britain, Minneapolis, University of Minnesota Press.

MOOSAVI, Leon (2014): "The racialization of Muslim converts in Britain and their experiences of Islamophobia", Critical Sociology, vol. 41, no. 1, pp. 41-56. https://doi.org/10.1177/0896920513504601. MORERAS, Jordi (1999): Musulmanes en Barcelona: espacios y dinámicas comunitarias, Barcelona, CIDOB. MOSSE, George L. (1961): "The mystical origins of National Socialism", Journal of the History of Ideas, vol. 22, no. 1, pp. 81-96. http://doi.org/10.2307/2707875.

- (1998): The crisis of German ideology: intellectual origins of the Third Reich, New York, H. Fertig.

MÜLLER-URI, Fanny \& OPRATKO, Benjamin (2016): "Islamophobia as anti-Muslim racism: racism without 'races', racism without racists", Islamophobia Studies Journal, vol. 3, no. 2, pp. 116-129.

NUSSBAUM, Martha C. (2012): The new religious intolerance: overcoming the politics of fear in an anxious age, Cambridge, Mass. \& London, The Belknap Press of Harvard University Press.

PETERS, Rudolph (2006): "«A dangerous book» Dutch public intellectuals and the Koran", EUI Working Papers, no. 39, http://cadmus.eui.eu/bitstream/handle/1814/6385/RSCAS-2006-39.pdf [accessed 21 April 2017].

PIPES, Daniel (1995): "There are no Moderates: Dealing with Fundamentalist Islam", The National Interest, no. 41 , pp. $48-57$.

- (2007): "Ban Islam?", New York Sun, 29 August.

- (2008): "A Democratic Islam?", The Jerusalem Post, 16 April, http://www.jpost.com/Opinion/Op-EdContributors/A-democratic-Islam [accessed 11 April 2017].

POLIAKOV, Léon (1984): Historia del antisemitismo. 3: el Siglo de las Luces, Barcelona, Muchnik editores.

PUSCHNER, Uwe (2002): "«One people, one Reich, one God». The völkische weltanschauung and movement", German Historical Institute London Bulletin, vol XXIV, no. 1, pp. 5-27.

RANA, Junaid (2007): "The story of Islamophobia", Souls, vol. 9, no. 2, pp. 148-161. http://dx.doi.org/10.1080/10999940701382607.

RATTANSI, Ali (2007): Racism: a very short introduction, Oxford \& New York, Oxford University Press.

RAVELLO, Enrique (2010): "Precisiones sobre el "antiislamismo»", Identidad y tradición, 5 October, http://identidadytradicion.blogia.com/2010/100501-precisones-sobre-el-antislamismo-.php [accessed 5 January 2017]

RICHARDSON, Joel (2006): Antichrist: Islam's awaited Messiah, Enumclaw, WA., Pleasant Word.

- (2009): The Islamic Antichrist: the shocking truth about the real nature of the beast, Los Angeles, WND Books.

ROBERTSON, Grayson R. (2011): The influence of dispensationalist theology on Evangelical perceptions of Muslims post-9/11, M.A. Thesis, Faculty of the School of Continuing Studies and the Graduate School of Arts and Sciences, Georgetown University, Washington, D.C.

ROGER, Maiol (2015): "Plataforma per Catalunya se hunde y pierde el 90\% de los concejales", El País, 26 May.

SELOD, Saher (2015): "Citizenship denied: the racialization of Muslim American men and women post9/11", Critical Sociology, vol. 41, no. 1, pp. 77-95. https://doi.org/10.1177/0896920513516022.

SELOD, Saher \& Embrick, David G. (2013): "Racialization and Muslims: situating the Muslim experience in race scholarship", Sociology Compass, vol. 7, no. 8, pp. 644-655. http://dx.doi.org/10.1111/soc4.12057.

SMITH, Christopher C. (2014): "«Ex-Muslims», Bible prophecy, and Islamophobia: rhetoric and reality in the narratives of Walid Soebat, Kamal Saleem, Ergun and Emir Caner", Islamophobia Studies Journal, vol. 2, no. 2, pp. 76-93.

SMITH, Jack (2011): Islam: the cloak of Antichrist, Enumclaw, Wash., Wine Press Pub.

SPENCER, Robert \& Ali, Daniel (2003): Inside Islam: a guide for Catholics. 100 questions and answers, West Chester, Ascension Press.

STERN, Fritz R. (1974): The politics of cultural despair: a study in the rise of the Germanic ideology, Berkeley, University of California Press. 
STOLCKE, Verena (1995): "Talking culture: new boundaries, new rhetorics of exclusion in Europe", Current Anthropology, vol. 36, no. 1, pp. 1-24. http://dx.doi.org/10.1086/204339.

TAL, Uriel (2004): Religion, politics and ideology in the Third Reich: selected essays, London \& New York, Routledge.

TYRER, David (2013): The politics of Islamophobia: race, power and fantasy, London, Pluto Press.

VERTOVEC, Steven (2002): "Islamophobia and Muslim recognition in Britain", in Haddad, Yvonne Y. (ed.): Muslims in the west: from sojourners to citizens, New York, Oxford University Press, pp. 19-35.

WELLER, Paul (2006): "Addressing religious discrimination and Islamophobia: Muslims and Liberal Democracies. The case of the United Kingdom", Journal of Islamic Studies, vol. 17, no. 3, pp. 295-325. https://doi.org/10.1093/jis/etl001.

WIEVIORKA, Michel (2009): El racismo: una introducción, Barcelona, Gedisa.

ZIMMERMANN, Moshe (1986): Wilhelm Marr, the patriarch of antisemitism, New York, Oxford University Press. 